\title{
Foliar water uptake in the needles of Pinus torreyana
}

\author{
Emily Tianshi ${ }^{(1)}$ Pao C. Chau $(\mathbb{D}$
}

Received: 19 July 2021 / Accepted: 24 January 2022 / Published online: 2 February 2022

(C) The Author(s) 2022

\begin{abstract}
The natural habitat of Pinus torreyana, the Torrey pine, is restricted to two locales in coastal Southern California that experience substantial fog and low clouds during the dry months of a Mediterranean climate. In similar semi-arid climate systems that encounter fog or low clouds, many plants can capture atmospheric moisture and are capable of direct foliar water uptake to reduce water stress. In this study, we investigated if the needles of $P$. torreyana are also capable of direct water uptake. In addition to water immersion, we measured the surface properties along a needle using microdroplets. The droplet contact angle is a measure of surface wettability, and the droplet absorption is a measure of localized foliar water uptake. The results showed that the entire length of the $P$. torreyana needle, including under the base sheath, is hydrophilic and capable of direct water uptake. The spatial gradients of the
\end{abstract}

Communicated by A. Joshua Leffler.

E. Tianshi

The Cambridge School, San Diego, CA, USA

e-mail: etianshi@stanford.edu

Present Address:

E. Tianshi

Stanford University, Stanford, CA, USA

P. C. Chau $(\bowtie)$

Department of Nanoengineering, University of California,

La Jolla, San Diego, CA, USA

e-mail: pcchau@eng.ucsd.edu wettability and the water uptake along the needle are relatively small. Moreover, the wettability and water uptake increase from young shoots to one-year and two-year old needles. Our results also showed that the decrease in water uptake at higher contact angles can be described by a linear regression. Compared with the leaves of four shrubs in the same habitat, Heteromeles arbutifolia, Malosma laurina, Rhus integrifolia, and Eriodictyon crassifolium, the P. torreyana needles have lower contact angles and higher water uptake rates.

Keywords Foliar uptake $\cdot$ Contact angle $\cdot$ Droplet uptake $\cdot$ Maritime chaparral $\cdot$ Pinus torreyana

\section{Introduction}

The ability to utilize atmospheric moisture from fog or dew to reduce water stress can be an important adaptive feature of plants in semi-arid climates. Studies on how plants might capture dew via aerial structures date back three centuries (Stone 1957a; Berry et al. 2019), and in some epiphytic Tillandsia species, atmospheric moisture uptake improves water balance (De Santo et al. 1976). Depending on the composition and physico-chemical properties, many leaf surfaces are wettable and provide pathways for foliar uptake of water and solutes (Fernández et al. 2017). Foliar water uptake (FWU) is recognized as a common mechanism that can be driven by a favorable water 
potential gradient (Schreel and Steppe 2020). The process of FWU has been reviewed extensively (Rundel et al. 1982), and more recent analyses (Dawson and Goldsmith 2018; Berry et al. 2019) have detailed many species with varying FWU capabilities spanning dozens of plant families across different ecosystems. Some examples include plants in montane cloud forests (Eller et al. 2013), coastal redwood forests (Burgess and Dawson 2004; Limm et al. 2009), and coastal shrubs (Emery 2016). These ecosystems encounter either persistent or seasonal fog and low cloud cover (FLCC), which moderates the climate in addition to providing atmospheric moisture.

FWU as a water subsidy has been recognized in conifers (Breshears et al. 2008), and the phenomenon of fog drip has been thoroughly studied in California coastal redwood forests (Dawson 1998; Burgess and Dawson 2004; Limm et al. 2009; Goldsmith et al. 2013). A small quantity of fog water is absorbed directly into the leaves of Sequoia sempervirens (Burgess and Dawson 2004). Foliar uptake can increase the leaf water content by $2-11 \%$ and helps reduce water stress during dry seasons (Limm et al. 2009).

Stone and coauthors (Stone et al. 1950, 1956; Stone 1957b) performed some of the earlier studies of pines using potted seedlings. Collectively, their results showed that Pinus coulteri, Pinus ponderosa, and Pinus jeffreyi can survive a period of drought in soil at the wilting point. Application of mist at nights further extended the survival of potted $P$. ponderosa seedlings from 64 to 94 days (Stone 1957b). Boucher et al. (1995) found that spraying mist just three seconds thrice weekly on potted Pinus strobus seedlings improved the shoot xylem water potential by $28 \%$. They attributed the improvement to foliar water uptake. For a population of Pinus muricata on one of the California Channel Islands, shade from low clouds and fog drip provide comparable contributions and together reduce annual drought stress by 56\% (Fischer et al. 2009) and peak water deficit by $70 \%$ (Baguskas et al. 2016b). With potted P. muricata saplings, Baguskas et al. (2016a) showed that fog immersion alone increased soil moisture by $40 \%$ and improved the carbon assimilation rate, and suggested that FWU is a probable mechanism.

Two studies involving Pinus sylvestris and Pinus radiata using detached needles also provided insights of foliar uptake (Leyton and Juniper 1963; Leyton and Armitage 1968). Leyton and coworkers measured surface wettability through sessile droplet contact angles and water uptake by immersing different sections of the needles in water overnight. They found that the needles of $P$. sylvestris absorbed water near and under the base sheath, while the needles of $P$. radiata absorbed moisture on the exposed needle surface. Leyton ascribed the difference to the adaptation of $P$. radiata to a climate with summer fog during dry seasons.

The object of the present study is Pinus torreyana C. Parry ex Carrière ssp. torreyana, a subspecies endemic to a coastal mesa in southern California that includes the confines of Torrey Pines State Natural Reserve (TPSNR). Together with another small population of the subspecies Pinus torreyana Parry ex Carrière ssp. insularis J. R. Haller on Santa Rosa Island, Pinus torreyana is a relic taxon (Haller, 1968) that is considered critically endangered and the rarest pine in North America (IUCN 2021). A paleoecological study revealed that the population of the pine was exceedingly small historically. Consequently, the genetic diversity of the pine is very low (Ledig and Conkle 1983; Whittall et al. 2010; Steele et al. 2021). Spatial distributions of the stand structure and recruitment pattern of the pine have been studied (Wells and Getis, 1999; Franklin and Santos 2011), and more recent efforts have investigated the evolutionary potential of the pine (Hamilton et al. 2017; Steele et al. 2021). However, these studies did not address FWU.

Both populations of $P$. torreyana are situated in coastal areas encountering FLCC during the dry seasons of a Mediterranean climate (Haller 1986; Williams et al. 2008). The benefits of FLCC on P. torreyana were demonstrated in two tree-ring studies. Williams et al. (2008) refined the work of Biondi et al. (1997) and showed that while precipitation in winter and spring affects soil moisture, there is a significant correlation of tree-ring widths to summertime cloud frequency. Our hypothesis is that $P$. torreyana can capture atmospheric moisture, which may explain one of the reasons how FLCC during the dry months is a factor in reducing water stress in the tree-ring studies. Moreover, $P$. torreyana has a relatively large foliage surface area that may help intercept fog or condense dew. The pine is diploxylon but on average has five needles per fascicle. The needles are long, usually reaching $200-280 \mathrm{~mm}$ and sometimes $300 \mathrm{~mm}$ beyond the base sheath. In this study, 
we investigated if Pinus torreyana can exhibit foliar uptake using detached needles. We measured droplet contact angles, and extending on the works by Leyton et al. $(1963,1968)$, we made use of droplet uptake rates to better assess spatial variations along a needle. We found that the needle surface is predominantly hydrophilic, and the needles are capable of direct water uptake. The spatial gradients of the contact angle and the water uptake are different, but there is a linear relationship between contact angle and local uptake flux.

\section{Materials and methods}

\section{Sampling site}

Pinus torreyana needles were collected on the campus of the University of California, San Diego, located on a mesa about $2 \mathrm{~km}$ south of TPSNR. The sampling location is at the top of a xeriscape ravine with chaparral vegetation. The trees were planted there as saplings in the 1990s. Using the ClimateWNA database and climate model (Wang et al. 2016), the mean annual rainfall at this site over the last decade (2011-2020) was $298 \mathrm{~mm}$, and the computed Hargreaves reference evapotranspiration was $1010 \mathrm{~mm}$. Over the same period at TPSNR, the mean rainfall and evapotranspiration were $289 \mathrm{~mm}$ and $964 \mathrm{~mm}$, respectively. Thus, the climate at the sampling site is similar to that of TPSNR. The annual rainfall at these sites during this decade was higher than the $262.6 \mathrm{~mm}$ commonly cited as the historic average over the San Diego coast by the National Weather Service (NWS). However, ClimateWNA has not posted data beyond 2020, and the NWS rainfall will be used to analyze data that spanned 2019-2021.

\section{Needle water content}

The water content of the needles was monitored for 24 months. Near the end of each month, five one-year old fascicles at head level were collected. Within an hour, both the beginning $15 \mathrm{~mm}$ near the base sheath, where the needles are not well separated, and the $30 \mathrm{~mm}$ uneven tip regions were excised, retaining a $160 \mathrm{~mm}$ minimum uniform segment. The cut ends were capped with a dab of silicone sealant smeared as a thin film. After the adhesive dried, the fascicles were weighed before being soaked in deionized water overnight in the dark. The saturated weight was measured after the needles were patted dry. For the desiccated weight, the fascicles were heated at $80{ }^{\circ} \mathrm{C}$ for $5 \mathrm{~h}$. The fractional water content is defined as $f_{w c}=\left(m-m_{d r y}\right) /\left(m_{s a t}-m_{d r y}\right)$, where $m$ is the weight of a given sample, and $m_{d r y}$ and $m_{\text {sat }}$ are the respective desiccated and saturated weights (Yamasaki and Dillenburg 1999).

\section{Electron microscopy}

We examined the surface of $P$. torreyana needles using environmental scanning electron microscopy (Quanta 200, FEI) to assess the extent of epicuticular wax coverage and surface roughness that might affect droplet measurements. Fresh needle samples were sputter coated with iridium to enhance conductivity before being placed on a sample mount.

\section{Contact angle}

Ten and 22 month old fascicles, hereafter named 1 and 2 year olds, respectively, were collected. The base sheath of freshly collected fascicles was stripped off. For each age class, six needles were taken from two adjacent fascicles. Each needle was taped to a horizontal surface. Three needles were placed with the abaxial, or curved, surface facing upward and the other three with the adaxial, or flat, surface facing upward. Droplets of $2 \mu 1$ deionized water were placed on the upper surface along the length of the needles at $20 \mathrm{~mm}$ intervals, with the distance measured from the edge of the base sheath. An additional droplet was applied to the midpoint of where the base sheath was to measure the properties of the surface covered by the base sheath. A side-view 2D image was taken with a digital microscope (Jiusion). The contact angles of the left and right edges of each droplet to the needle surface were measured using the protractor function in the image processing application, GIMP.

\section{Water uptake rate}

Water uptake was measured through needle immersion and droplet uptake. We first measured water uptake in different sections of the needle following the immersion method used by Leyton et al. (1963, 1968). The excised end of a fascicle, including the 
base sheath, was sealed with Parafilm. Afterward, the fascicle was immersed, with the tip end down, in deionized water to a designated depth. The weight gain was recorded at $18 \mathrm{~min}, 1 \mathrm{~h}$, and $24 \mathrm{~h}$. Five fascicles were used for each immersion depth. The brief 18 min was chosen such that the uptake would be well under the absorption capacity of the needle based on droplet measurements to limit water transport within the needle.

In the second method, we took droplet uptake measurements. In step with the contact angle procedure in the previous section, after the $2 \mu \mathrm{l}$ droplets were applied to the surface, the times for their disappearance were recorded. The droplets were spaced $20 \mathrm{~mm}$ apart to ensure that the droplets would not interact during the initial uptake phase (Fig. 1). Concurrently, three $2 \mu$ droplets were applied on Parafilm to measure the evaporation rate. The rate of water uptake into the needle is the total loss rate minus the evaporation rate, $r_{\text {uptake }}=r_{\text {tot }}-r_{\text {evap }}$. The uptake flux is calculated as the net uptake rate divided by the footprint area of each droplet. For a $2 \mu$ droplet, its footprint area stays constant until the end. The droplet uptake flux will also be referred to as a local uptake flux, as opposed to an average over the needle surface. To expand the range of probable contact angles, 13 young shoots under four months old and varying between 11 and $96 \mathrm{~mm}$ were used. On each, a droplet was applied to the base sheath region and another on the exposed needle to measure the droplet uptake rates.

\section{Comparison with selected plants}

To address how $P$. torreyana compares to other species within its natural habitat, several coastal shrubs

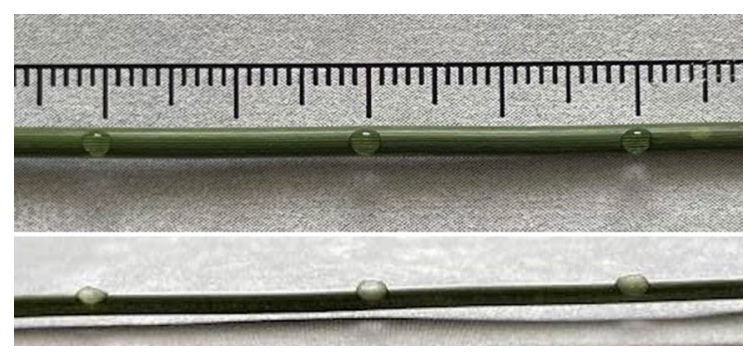

Fig. 1 Photos illustrating the spacing of three droplets $20 \mathrm{~mm}$ apart on a needle section. Top panel: top view; bottom panel: side view with large, broad, evergreen foliage were chosen. They are Heteromeles arbutifolia (toyon), Malosma laurina (laurel sumac), and Rhus integrifolia (lemonadeberry) from maritime chaparral, and Eriodictyon crassifolium (thick-leaf yerba santa) from coastal sage scrub. For each plant, five $2 \mu \mathrm{l}$ droplets of deionized water were applied widely spaced on the adaxial surface of three leaves. As with the procedures on the needles, images of the droplets were taken to measure the contact angles, and droplet disappearance times were recorded. Droplets on Parafilm were used as the evaporation control.

A comparison of the desiccation of detached leaves was also performed. Another five leaves from each shrub and five pine fascicles were used. Images of the leaves were taken, and their areas were calculated with a pixel count calibration on GIMP. The needle area was calculated using ruler and micrometer measurements. All leaves were left to dry without cover under laboratory ambient conditions. The weights were taken daily. The daily weight loss rate, taken to be that of water, was normalized by the respective total adaxial and abaxial area of each leaf to calculate the desiccation flux.

\section{Statistical analysis}

To test for normality and identify probable outliers, boxplot, Shapiro-Wilk test, and quantile-quantile plot were applied to each data set and regression. To handle data with high variability, linear regression using weighted least squares with internally studentized residues was used to reduce the weights of scattered points that were not outliers. Sample standard error bars were calculated from the three needles used for each surface. All analyses used a significance level of 0.05 and were carried out in the statistical software $\mathrm{R}$ (R Core Team 2021) running under Rstudio (RStudio Team 2021).

Due to surfaces with nonuniform properties, droplets have different contact angles at each edge of the 2D image. Within this study, the maximum difference of the contact angle on each side of the droplet was $7.3^{\circ}$ with a mean of $0.9^{\circ}$ on the abaxial surface. The maximum difference on the adaxial surface was $8.1^{\circ}$ with a mean of $1^{\circ}$. In the analyses, the average of the two edge readings was taken as the contact angle of a given droplet. Droplets were placed $20 \mathrm{~mm}$ apart as guided by a scale. On the abaxial surface, 
the maximum placement error in absolute value was $2.9 \mathrm{~mm}$ with a mean error of $0.07 \mathrm{~mm}$, and on the adaxial surface, the maximum error was $2.1 \mathrm{~mm}$ with a mean of $0.06 \mathrm{~mm}$. Hence, in the regressions of contact angle and uptake rate versus location, the $x$-axis location error was taken to be negligible. Standard error bars are not based on repeated sampling of the same needle, as needle properties change after each use. Instead, needles from the same or adjacent fascicles were used. Hence the standard error bars are an indication of the variability of similar needles.

\section{Results}

\section{Needle water content}

The fractional water content, $f_{w c}$, of the needles varies in a pattern that reflects seasonal change in rainfall. The value averaged $0.84 \mathrm{~g} / \mathrm{g}(\mathrm{SE}=0.01)$ during the survey period beginning in October 2019 (dashed line, Fig. 2). October is taken as the beginning of the local rainy season, which lasts until April. There was no precipitation in October 2019, but over the year from October 2019 to September 2020, the cumulative rainfall from NWS was $345 \mathrm{~mm}$, which was $32 \%$ above the historic average of $262.6 \mathrm{~mm}$. After several large rainstorms in November and December of 2019, the $f_{w c}$ was as high as $0.94 \mathrm{~g} / \mathrm{g}$. The weather was unusually warm and dry at the beginning of 2020. The total precipitation of April 2020 was reasonable, but it all came at the beginning of the month based on the daily record (not shown), and the $f_{w c}$ decreased to $0.76 \mathrm{~g} / \mathrm{g}$ near the end of April 2020. After the unusually wet year, the second year beginning in October 2020 was extremely dry with a cumulative rainfall of $133 \mathrm{~mm}$, about $51 \%$ of the historic average. The highest $f_{w c}$ during this year was $0.87 \mathrm{~g} / \mathrm{g}$ at the end of February 2021. During the dry months, generally from May to September, the needles maintained a $f_{w c}$ roughly above $0.8 \mathrm{~g} / \mathrm{g}$ despite the lack of rainfall. In fact, from May to September 2020, the $f_{w c}$ increased gradually through the summer, and recovered from the low point of April 2020.

\section{SEM}

A scanning electron micrograph of one-year-old $P$. torreyana needle surfaces indicates that there are only remnants of epicuticular wax, especially on the abaxial surface (Fig. 3). On both the abaxial and adaxial surfaces, one can identify spinose teeth at the margins and stomata with Florin rings of epicuticular wax. The remaining coverage of vestigial epicuticular wax is uneven. There are more residues on the adaxial surface, where there is epicuticular wax between stomata and between some stomatal lines. The uneven surface is a source of variability in droplet measurements.
Fig. 2 Records of needle fractional water content, $f_{w c}$ (g/g), (upper panel and left vertical axis) with standard error bars, and the dashed line is the average $f_{w c}$ over the two-year period. The bar chart (lower panel and right vertical axis) is the NWS monthly cumulative rainfall from October 2019 to September 2021

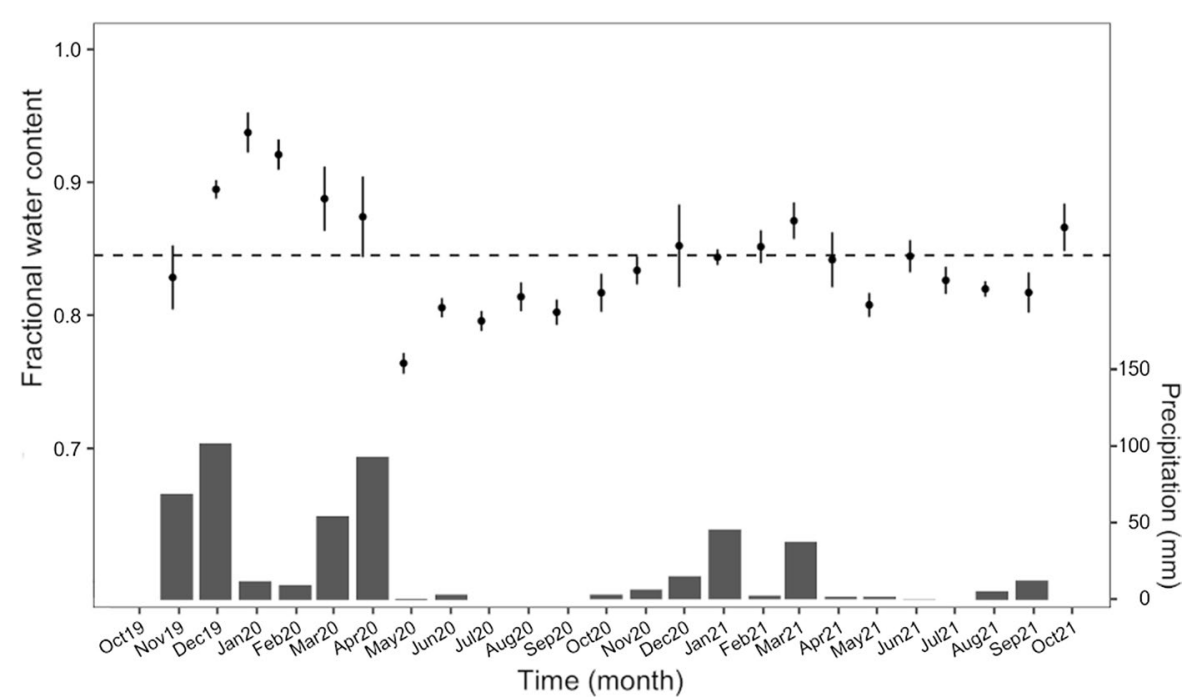


Fig. 3 Scanning electron micrographs of one-year old needles: a abaxial surface, 130x, b adaxial surface, 120x. Scale bars represent $400 \mu \mathrm{m}$

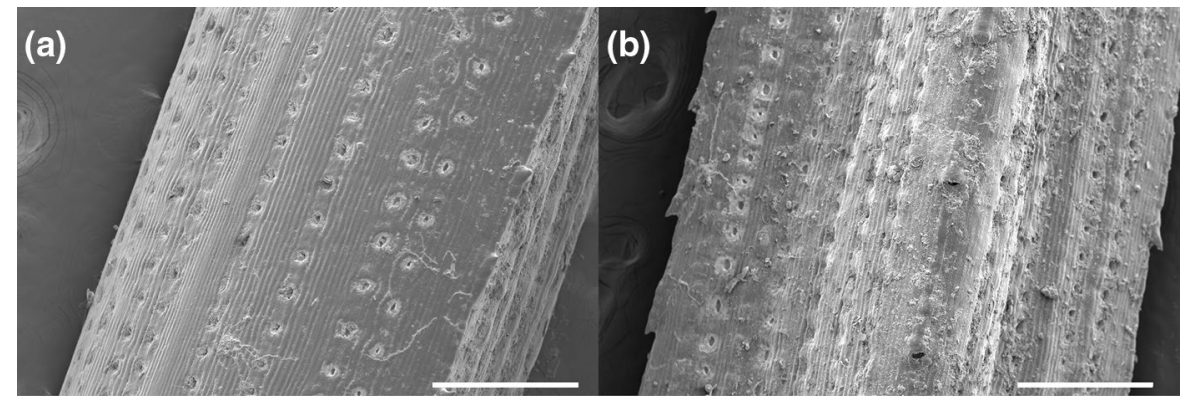

Foliar uptake by droplet uptake

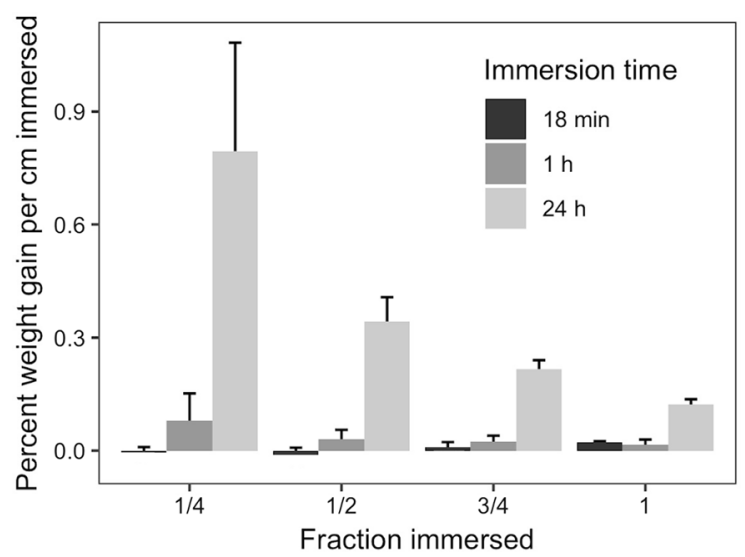

Fig. 4 Percentage weight gain with standard error bars of needles for different time periods normalized by the immersed length in water for different durations

Foliar uptake by fractional immersion

The immersion time strongly influences the water uptake normalized by the immersion length (Fig. 4). This dependence is most evident when the needles are immersed for $24 \mathrm{~h}$. When a smaller fraction of the needles is immersed, the normalized weight gain is larger. As a larger fraction of the needles is immersed, this weight gain decreases. This weight gain pattern is also exhibited with the $1 \mathrm{~h}$ immersion but is much less pronounced. When the needles are submerged only for $18 \mathrm{~min}$, the normalized weight gains of the one-quarter and one-half immersed needles are so small that they appear as a slight weight loss. The normalized weight gain of the fully submerged needles is higher than the three-quarters immersed at $18 \mathrm{~min}$.
Droplet measurements provide a better characterization of probable spatial distributions of wettability and foliar uptake. The adaxial contact angle and droplet uptake flux results are in Fig. 5a, b, while the corresponding abaxial surface values are in Fig. $5 \mathrm{c}$, d. As suggested by the SEM images, there is large variability because of the uneven surfaces. The droplet measurements showed that while there are local variations in contact angles and water uptake rates, the spatial gradients are relatively small, especially that of the droplet uptake flux. The contact angles are all under $65^{\circ}$, but both abaxial and adaxial surfaces of the two-year old needles have lower values; they are more wettable. However, the spatial gradients have small differences.

The droplet uptake fluxes (Fig. 5b, d), except for the year-2 adaxial surface, are lower toward the needle tip, where the contact angles are larger, meaning less wettable. The slope of the year-2 adaxial surface is negative but very small (Table 1). Both the contact angle and uptake flux regressions of the year-2 adaxial surface are not statistically significant ( $p=0.051$ and 0.33 , Table 1$)$, and the coefficient of determination, $r^{2}$, is as low as 0.11 . The other three slopes are statistically significant, but considering the small gradient, which is in the order of the magnitude of $10^{-4} \mathrm{mg} \mathrm{cm}^{-2} \mathrm{~s}^{-1}$ per $\mathrm{cm}$ change, the physical functional dependence of the spatial variation along the needle is small.

The two-year old surfaces have a higher uptake flux than the one-year olds, corresponding to the lower contact angles. Nonetheless, the functional dependence is not definitive. The increase in the uptake fluxes of the year- 2 surfaces is not proportional to the respective decrease in contact angles. 

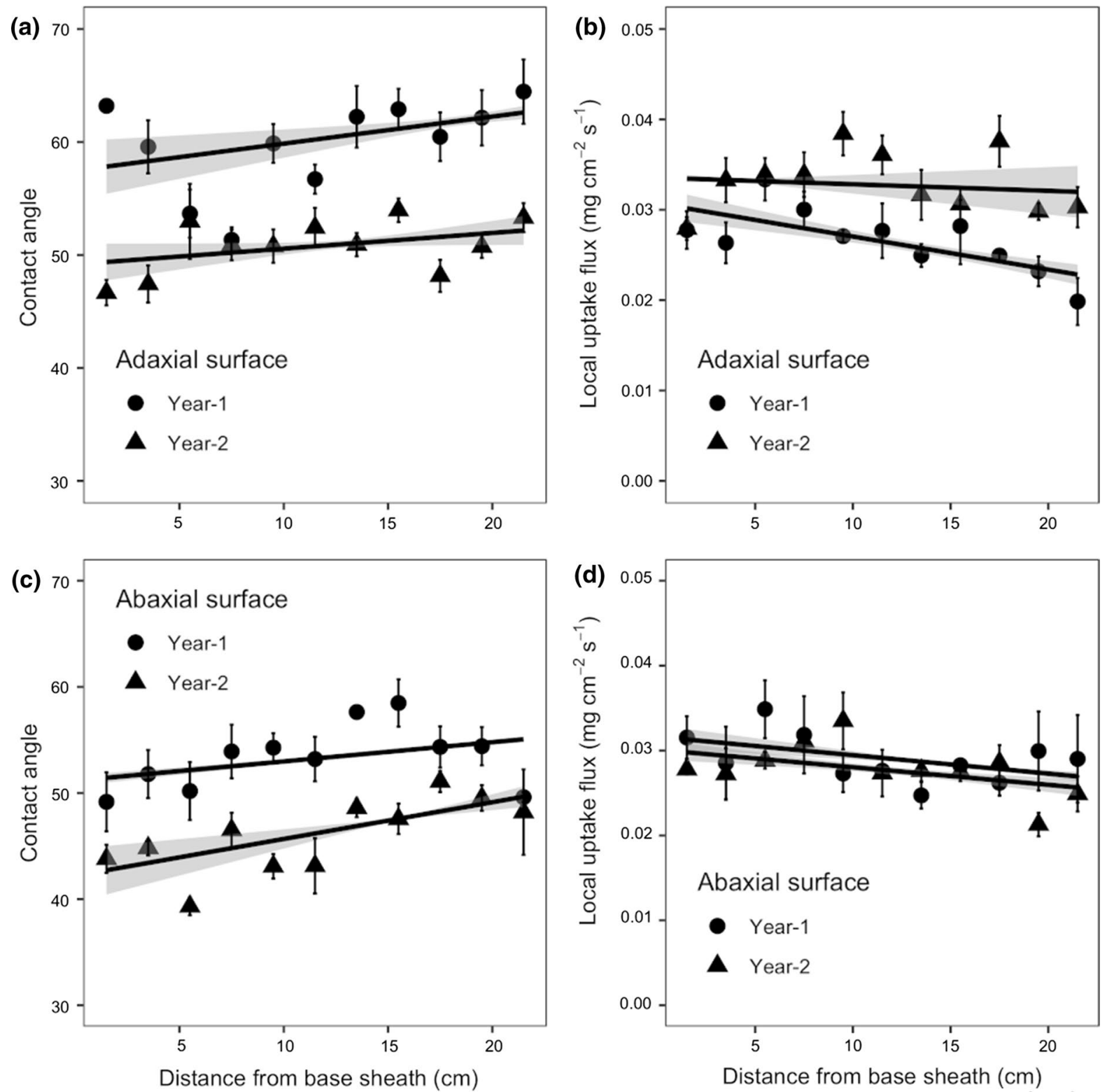

Fig. 5 Contact angle and local (droplet) water uptake flux along one-year old and two-year old needles; $\mathbf{a}$ and $\mathbf{b}$ adaxial surfaces, $\mathbf{c}$ and $\mathbf{d}$ abaxial surfaces. All error bars are standard

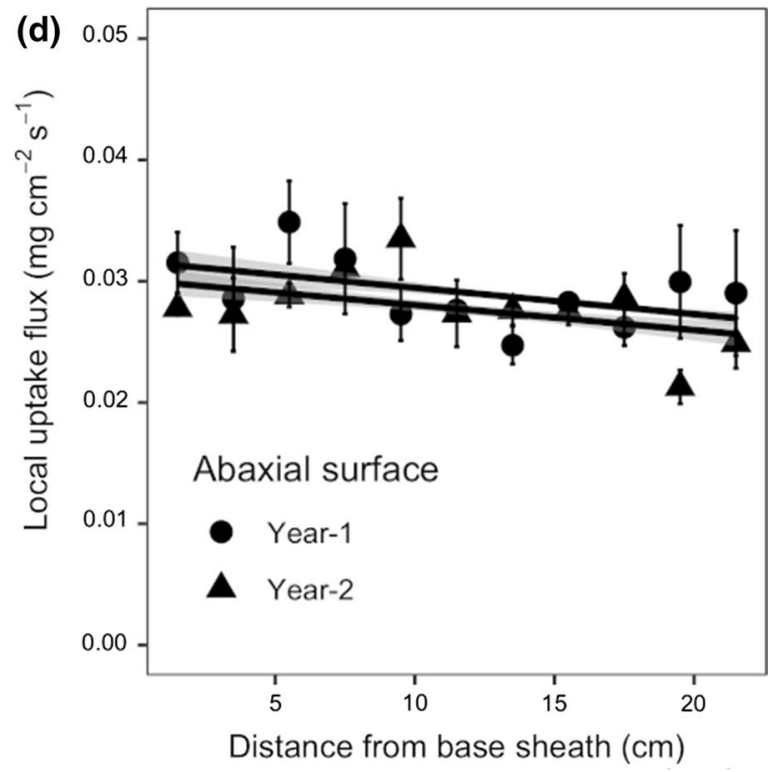

errors. The results of weighted least squares with $95 \%$ confidence bands, and statistics summaries in Table 1

The spatial gradient of the uptake flux also does not strictly follow that of the contact angle.

Correlation of the local uptake flux with contact angle

To explore the functional dependence of the local droplet water uptake flux versus contact angle, a

regression was applied to all the data in Fig. 5 with additional data from young shoots (Fig. 6). The decrease in uptake flux at higher contact angles can be described by a linear regression. The contact angles of the droplets on mature (year-1 and year-2) needles are predominately below $65^{\circ}$. At the low end $\left(<45^{\circ}\right)$ and the high end $\left(\sim 60^{\circ}\right)$, there is some consistency in that a lower contact angle 
Table 1 Summary of weighted least squares of contact angle and local droplet water uptake flux.

\begin{tabular}{llll}
\hline Contact angle & & & \\
\hline Age & Slope & $r^{2}$ & $p$ \\
\hline Adaxial & & & 0.0036 \\
Year-1 & $0.24 \pm 0.06$ & 0.63 & 0.051 \\
Year-2 & $0.14 \pm 0.06$ & 0.36 & $<0.001$ \\
Abaxial & $0.18 \pm 0.01$ & 0.95 & $<0.001$ \\
Year-1 & $0.35 \pm 0.07$ & 0.72 & $p$ \\
Year-2 & & & $<0.001$ \\
\hline Local uptake flux & Slope & $r^{2}$ & 0.33 \\
\hline Age & & 0.84 & $<0.001$ \\
\hline Adaxial & $-3.7 \pm 0.5 \times 10^{-4}$ & 0.11 & $<0.001$ \\
Year-1 & $-0.7 \pm 0.7 \times 10^{-4}$ & & 0.77 \\
Year-2 & $-2.2 \pm 0.4 \times 10^{-4}$ & 0.75 & $p e r$ \\
Abaxial & $-2.1 \pm 0.4 \times 10^{-4}$ & & \\
Year-1 & & & \\
Year-2 & & & \\
\hline
\end{tabular}

The slope of the contact angle regression is degree per cm change, and the slope of the local uptake flux is $\mathrm{mg} \mathrm{cm}^{-2} \mathrm{~s}^{-1}$ per $\mathrm{cm}$ change

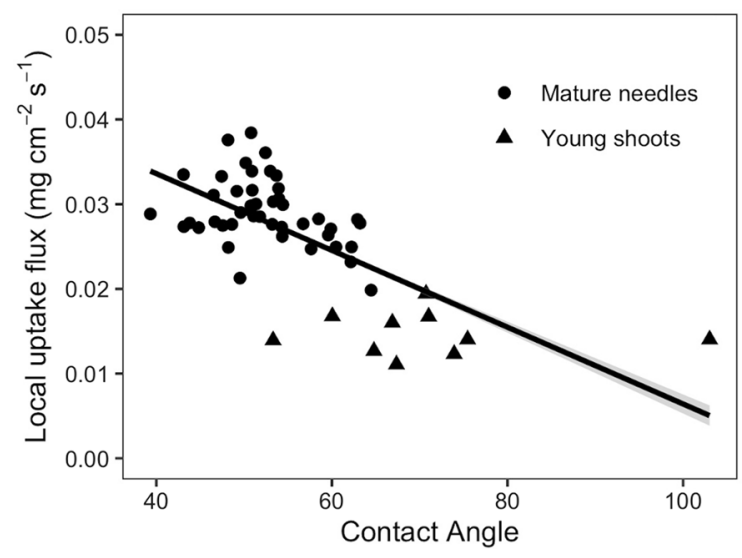

Fig. 6 Correlation of local water uptake flux with contact angle with weighted least squares and $95 \%$ confidence band. The error bars are standard errors of the water uptake flux. The slope is $-4.5 \times 10^{-4} \mathrm{mg} \mathrm{cm}^{-2} \mathrm{~s}^{-1}$ per degree change $\left(r^{2}=0.94\right.$, $p<0.001)$. The mature needles are the collection of year- 1 and year-2 needles

corresponds with a higher uptake flux. However, in the range roughly from 50 to $55^{\circ}$, the variability of the uptake flux is extremely high. The contact angles of droplets on young shoots are higher, between 60 and $80^{\circ}$, but there are exceptions, as shown by the hydrophobic droplet at $103^{\circ}$.
Comparison with other plants

The $P$. torreyana needles were compared with four local coastal shrubs with broad, evergreen foliage using desiccation as an approximation of how well the leaves can retain water (Fig. 7). The leaves desiccate via evaporation relatively quickly in the beginning, but water loss levels off after the first week. $E$. crassifolium loses water most rapidly, with a precipitous drop in weight within a few days (Fig. 7a), which corresponds with a high desiccation flux (Fig. 7b). $M$. laurina also loses water relatively quickly, while $H$. arbutifolia has a steadier decrease. $R$. integrifolia retains its water almost as well as $P$. torreyana for the first five days, after which it starts to lose water more quickly in an unsteady pattern. In contrast, $P$. torreyana never exhibits a steep drop in weight or sharp rise in desiccation flux. The needles lose water very gradually.

The wettability and fractional water content of the pine, using data from Fig. 5, compare favorably to the local shrubs (Table 2). The $f_{w c}$ values of the young shoots and pine needles are between 0.82 and $0.89 \mathrm{~g} / \mathrm{g}$, not much lower than the three chaparral shrubs $(0.88$ to $0.91 \mathrm{~g} / \mathrm{g})$ and higher than E. crassifolium. The adaxial leaf surfaces of the three chaparral 
Fig. 7 Comparison of desiccation loss of year-1 $P$. torreyana needles with four broadleaf shrubs: a relative weight as compared with the initial weight, $\mathrm{m} /$ $\mathrm{m}_{0}, \mathbf{b}$ desiccation flux $\mathrm{mg}$ $\mathrm{cm}^{-2} \mathrm{~s}^{-1}$. All error bars are standard errors
Table 2 Comparison of average contact angle and droplet uptake flux with sample standard errors of adaxial surfaces. The surface under the cylindrical base sheath has no orientation.

The uptake ratio is the uptake flux relative to the year- 2 surface, $f_{w c}$ is the initial sample fractional water content, and $n$ is the number of droplets used
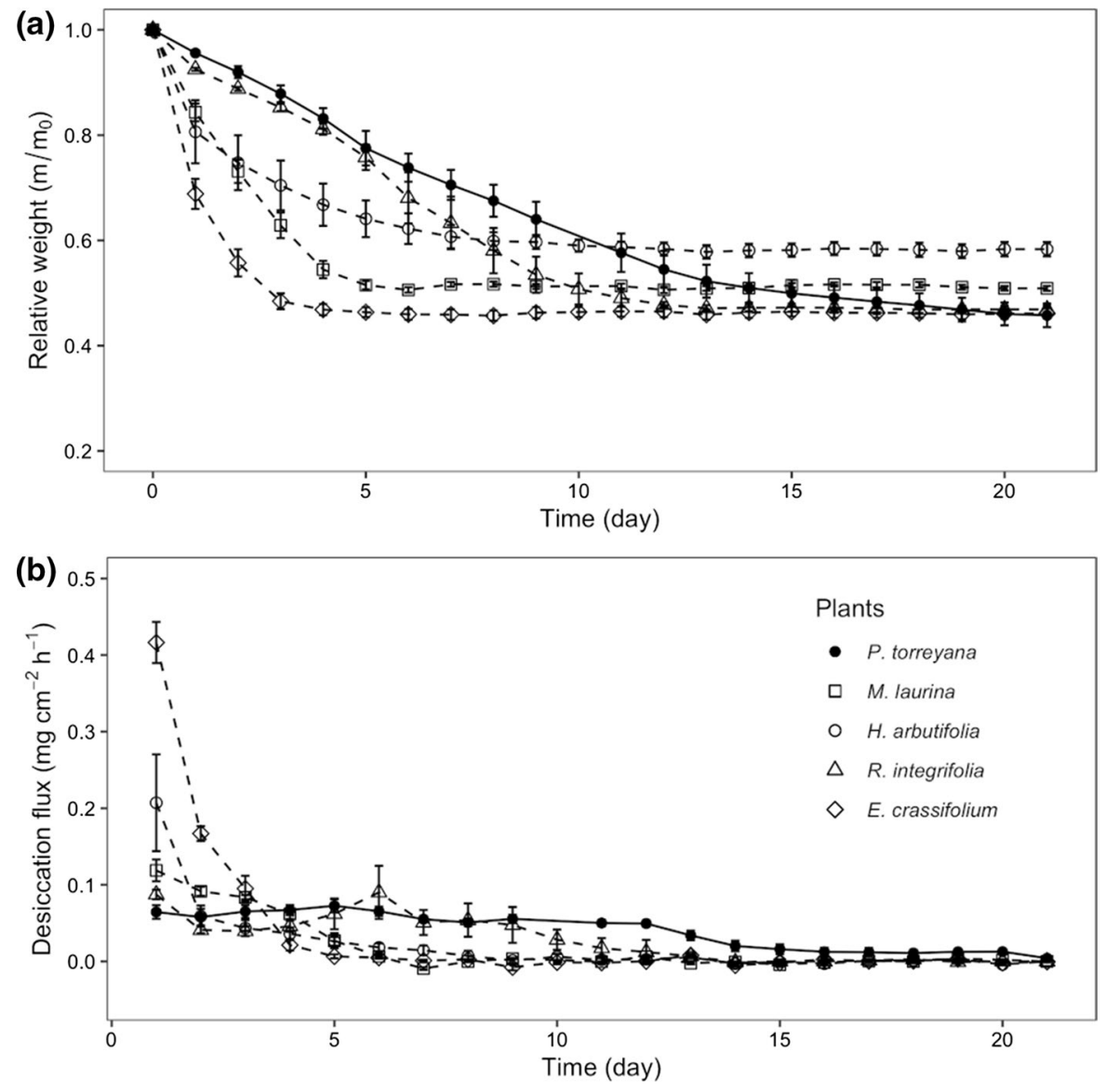

\begin{tabular}{lcllll}
\hline Plant & Contact angle $\left(^{\circ}\right)$ & Uptake flux $\left(\mathrm{mg} \mathrm{cm}^{-2} \mathrm{~s}^{-1}\right)$ & Uptake ratio & $f_{w c}$ & $n$ \\
\hline E. crassifolium & $112.9 \pm 9.0$ & $0.15 \pm 0.18 \times 10^{-2}$ & 0.05 & 0.75 & 15 \\
M. laurina & $70.7 \pm 10.6$ & $1.09 \pm 0.10 \times 10^{-2}$ & 0.33 & 0.88 & 15 \\
H. arbutifolia & $46.9 \pm 5.9$ & $1.39 \pm 0.16 \times 10^{-2}$ & 0.42 & 0.88 & 15 \\
R. integrifolia & $49.5 \pm 6.5$ & $1.72 \pm 0.20 \times 10^{-2}$ & 0.52 & 0.91 & 15 \\
P. torreyana & & & & & \\
Year-2 needles & $50.7 \pm 4.4$ & $3.30 \pm 0.48 \times 10^{-2}$ & 1 & 0.85 & 33 \\
Year-1 needles & $59.1 \pm 6.3$ & $2.72 \pm 0.59 \times 10^{-2}$ & 0.82 & 0.89 & 33 \\
Year-1, under sheath & $66.1 \pm 5.0$ & $1.32 \pm 0.14 \times 10^{-2}$ & 0.40 & & 6 \\
Young shoots & $70.6 \pm 4.2$ & $1.47 \pm 0.01 \times 10^{-2}$ & 0.45 & 0.82 & 13 \\
Young, under sheath & $74.5 \pm 2.9$ & $1.22 \pm 0.01 \times 10^{-2}$ & 0.37 & & 13 \\
\hline
\end{tabular}

shrubs are hydrophilic with contact angles in the 50 to $70^{\circ}$ range, including $R$. integrifolia, which is distinctly sclerophytic. The exception is E. crassifolium; its leaf surface is hydrophobic with an average contact angle of $112.9^{\circ}$. The average contact angle of the year- 2 needles is about $51^{\circ}$, slightly higher than those of $H$. arbutifolia, and $R$. integrifolia, and lower than that of $M$. laurina. The year- 1 needles have higher contact angles, averaging $66^{\circ}$. Under the year- 1 needle base sheath and also the young needle shoots, the contact angles, near $70^{\circ}$, are close to that of $M$. laurina. 
All three chaparral leaves are capable of foliar uptake, but their uptake fluxes are lower than the pine needles (see uptake ratio using year-2 needles as the base point in Table 2). A more notable difference is with the young shoots. Their average contact angle is similar to that of M. laurina, but they have a higher uptake flux. In fact, the uptake flux of the young shoots is comparable to that of $H$. arbutifolia $\left(1.47 \times 10^{-2}\right.$ vs. $1.39 \times 10^{-2} \mathrm{mg} \mathrm{cm} \mathrm{cm}^{-2}$, Table 2$)$, which has a lower average contact angle. The surface under the base sheath has a slightly higher contact angle than the corresponding exposed needle surface, with a proportionate decrease in the uptake flux. The water uptake flux of E. crassifolium is small but not negligible.

\section{Discussion}

The natural habitat of $P$. torreyana is restricted to two coastal mesas with seasonal FLCC. In this study, we found that Torrey pine needles can retain water reasonably well during the dry months, and for the first time, showed that the needles are capable of direct water uptake. Furthermore, we were able to probe the spatial distribution of the properties along a needle using droplet measurements.

Needle water content during the dry months

The monthly fractional water content exhibits seasonal fluctuations and is higher during rainy months (Fig. 2), but the $f_{w c}$ values do not continue to drop during the dry months. The water content is influenced by hot days and FLCC. In April 2020, the total monthly rainfall was high $(94 \mathrm{~mm})$, but it came early in the month, followed by several days with temperatures as high as $32{ }^{\circ} \mathrm{C}$ per NWS records. As a result, the $f_{w c}$ dropped to 0.76 near the end of April 2020. The onset of FLCC was early May 2020 based on local weather reports, and the FLCC might have prevented the $f_{w c}$ from decreasing. In June 2020, for example, the NWS temperatures were as high as $34{ }^{\circ} \mathrm{C}$ in the middle of the month, but the $f_{w c}$ stayed near $0.80 \mathrm{~g} / \mathrm{g}$ despite the lack of rainfall. The presence of FLCC may also explain the $f_{w c}$ in 2021. April 2021 was a dry month, but with early onset of FLCC, the $f_{w c}$ dropped to only $0.81 \mathrm{~g} / \mathrm{g}$. The FLCC became consistent and heavy starting in May 2021, and the
NWS temperature did not go above $24^{\circ} \mathrm{C}$ in May and June of 2021. The $f_{w c}$ stayed just under the $0.84 \mathrm{~g} / \mathrm{g}$ average throughout the rest of summer 2021.

Onset of steady FLCC begins in southern California as early as May (Clemesha et al. 2016). Dense FLCC, especially when low clouds prevail until mid-day, reduces solar radiation. Thus, FLCC moderates the maximum daytime temperature, reduces evapotranspiration, and narrows the water deficit. Direct water uptake further improves the water balance (Clemesha et al. 2016; Torregrosa et al. 2016; Williams et al. 2008). The combination of these processes may explain how the $f_{w c}$ did not continue to decrease through the dry months.

Comparison with related works with detached needles

In the immersion experiment, the partially immersed needles can have a disproportionately large weight gain when normalized by the immersion length (Fig. 4). This pattern may suggest that the distal portion of the needles is capable of higher water uptake. However, the normalized weight gain of partially immersed needles decreases from 24 to $1 \mathrm{~h}$ immersion, and this pattern is not evident at $18 \mathrm{~min}$. It is apparent that after water is absorbed near the distal end, it can be transported to the proximal part of the needle. This internal transport is less important with a lower immersion time or as more of the needle is immersed. It is evident that fractional immersion is not a good method to measure spatial variations.

Leyton et al. $(1963,1968)$ demonstrated that water uptake pattern is associated with needle surface properties. Extensive epicuticular wax with tubular morphology was observed for $P$. sylvestris needles but covers only a portion of $P$. radiata needles. The needles of $P$. sylvestris have average contact angles of $85.7^{\circ}$ and $77.3^{\circ}$ on the adaxial and abaxial surfaces, respectively. In contrast, $P$. radiata needles have lower contact angles, with average values of $57.6^{\circ}$ and $72.6^{\circ}$, respectively, for the adaxial and abaxial surfaces. The exposed $P$. radiata needle surface is capable of water uptake, unlike $P$. sylvestris, which absorbs water predominantly under the base sheath. In contrast, $P$. torreyanna needles have lower contact angles, and there are smaller differences in wettability and water uptake between the adaxial and abaxial 
surfaces. The spatial gradients, especially for the uptake flux, are small.

Furthermore, the surface underneath the $P$. torreyanna base sheath is hydrophilic, albeit having lower wettability. The sheath material is fibrous and very water absorbent. Many fascicles in the upper branches are spreading and ascending. It is conceivable that condensed droplets may roll downward and be absorbed in the base sheath. Nonetheless, the length of the base sheath of matured fascicles is usually under $20 \mathrm{~mm}$, and hence, the region provides only a small supplement to the long, exposed needle. Overall, the physical attributes of $P$. torreyana are better equipped to capture atmospheric moisture than $P$. radiata. With three-needle fascicles that vary between 90 and $150 \mathrm{~mm}$ in length, $P$. radiata has a much smaller needle surface area than $P$. torreyana. Furthermore, the abaxial surface of $P$. radiata on average has a higher contact angle, implying a lower water uptake rate. In contrast, the entire length of the $P$. torreyana needles and its small sheath base are capable of foliar water uptake.

Implication of the measured uptake rates

In the droplet measurements (Fig. 5), the year-1 surfaces have higher contact angles and lower uptake rates than the year- 2 needles. The young shoots in turn have an average contact angle higher than that of year-1 surfaces (Table 2). Similar changes from young to older needles have also been observed (Leyton and Armitage 1968). Cape (1983) measured a decrease in the contact angles of a young Pinus sylvestris needle from above $100^{\circ}$ to under $90^{\circ}$ in four months. Two-year old needles had contact angles as low as $75^{\circ}$. The decrease in older foliage can be ascribed to cuticle damage and degradation caused by weathering or air pollution (Lin et al. 2001; Berry et al. 2019; Schreel and Steppe 2020). While younger needles tend to have a less hydrophilic surface, a study of coastal Pinus muricata showed that with a shallower root system, saplings benefit more from fog drip than adult trees (Baguskas et al. 2016b), and FWU by itself represents only one aspect of how the pines manage water balance.

The local water uptake flux measured in P. torreyana detached needles is high. The measurements have an order of magnitude of $0.01 \mathrm{mg} \mathrm{cm}^{-2} \mathrm{~s}^{-1}$, which is equivalent to $5.6 \mathrm{mmol} \mathrm{m}^{-2} \mathrm{~s}^{-1}$. This is above the high end of transpiration fluxes of $2 \mathrm{mmol} \mathrm{m}^{-2} \mathrm{~s}^{-1}$ and FWU fluxes of $0.39 \mathrm{mmol} \mathrm{m} \mathrm{m}^{-2} \mathrm{~s}^{-1}$ in a survey by Berry et al. (2019). Using S. sempervirens leaves, Burgess and Dawson (2004) measured an average uptake flux of $0.89 \mathrm{mmol} \mathrm{m}^{-2} \mathrm{~s}^{-1}$. While the present results demonstrate that the $P$. torreyana needles are physically capable of water uptake, the measurements are higher than realistic in situ conditions in which the uptake would be modulated by hydraulic redistribution (Eller et al. 2013; Berry et al. 2019; Schreel and Steppe 2020).

Comparison with other plants

Without extensive epicuticular wax coverage, there is a trade-off between higher cuticular transpiration versus atmospheric moisture uptake (Leyton and Armitage 1968; Kerstiens 1996; Williams et al. 2008). Otherwise, $P$. torreyana would be growing among other pines in inland habitats or in chaparrals away from the coastal mesa. Leyton and Armitage (1968) considered that while $P$. radiata is adapted to the California coastal "fog belt," the species might not be very drought tolerant. They suggested that the capability of this pine to uptake moisture from its foliage could help maintain water balance and would have considerable survival value.

In terms of retaining water and FWU, the desiccation experiment showed that $P$. torreyana compares favorably with the leaves of the maritime chaparral broadleaf shrubs. The detached needles do not lose water as quickly, and the pine has a higher foliar uptake flux. Two of the shrubs, $H$. arbutifolia and $R$. integrifolia, have been reported to be capable of FWU (Berry et al. 2019).

The shrub, E. crassifolium, has very different properties. With its tomentose surface, a carefully placed droplet can be suspended on top of the hairs with hydrophobic contact angles. As the droplet becomes smaller via evaporation, it slips through the hairs to reach the surface. These two wetting modes are referred to as the Cassie-Baxter and Wenzel states (Dorrer and Rühe 2007). The E. crassifolium leaf is extremely absorbent if water is in direct contact with its surface, consistent with how it loses moisture the fastest (Fig. 7a). In this respect, if a leaf submersion method was used instead, the leaves of E. crassifolium would be shown to be capable of direct water uptake. 
In conclusion, we have demonstrated that $P$. torreyana is capable of foliar water uptake and compares favorably to some local coastal broadleaf shrubs. We showed that small droplets can be used to measure wettability and water uptake along the needles of $P$. torreyana. However, the uptake rates measured in detached needles are high and cannot be representative of in situ conditions. Nonetheless, we hope this study will foster more detailed studies of this rare pine.

Acknowledgements The authors would like to thank the anonymous reviewers and the editor for constructive comments, and Christopher Coaty and Victoria Petrova for their help in acquiring the ESEM images.

Author contributions Not applicable.

Funding Not applicable.

Data availability Not applicable.

Code availability Not applicable.

\section{Declarations}

Conflicts of interest The authors declare no competing interests.

Ethical approval Not applicable.

Informed consent Not applicable.

Consent for publication Not applicable.

Research involving human and animal participants Life science journals that report the results of studies involving humans and/or animals.

Open Access This article is licensed under a Creative Commons Attribution 4.0 International License, which permits use, sharing, adaptation, distribution and reproduction in any medium or format, as long as you give appropriate credit to the original author(s) and the source, provide a link to the Creative Commons licence, and indicate if changes were made. The images or other third party material in this article are included in the article's Creative Commons licence, unless indicated otherwise in a credit line to the material. If material is not included in the article's Creative Commons licence and your intended use is not permitted by statutory regulation or exceeds the permitted use, you will need to obtain permission directly from the copyright holder. To view a copy of this licence, visit http://creativecommons.org/licenses/by/4.0/.

\section{References}

Baguskas SA, King JY, Fischer DT, D’Antonio CM, Still CJ, Baguskas SA, King JY, Fischer DT, D’Antonio CM, Still CJ (2016a) Impact of fog drip versus fog immersion on the physiology of Bishop pine saplings. Funct Plant Biol 44:339-350. https://doi.org/10.1071/FP16234

Baguskas SA, Still CJ, Fischer DT, D’Antonio CM, King JY (2016b) Coastal fog during summer drought improves the water status of sapling trees more than adult trees in a California pine forest. Oecologia 181:137-148. https:// doi.org/10.1007/s00442-016-3556-y

Berry ZC, Emery NC, Gotsch SG, Goldsmith GR (2019) Foliar water uptake: processes, pathways, and integration into plant water budgets. Plant Cell Environ 42:410-423. https://doi.org/10.1111/pce.13439

Biondi F, Cayan DR, Berger WH (1997) Dendroclimatology of torrey pine (Pinus torreyana Parry ex Carr.). Am Midl Nat 138:237-251. https://doi.org/10.2307/2426817

Boucher J-F, Munson AD, Bernier PY (1995) Foliar absorption of dew influences shoot water potential and root growth in Pinus strobus seedlings. Tree Physiol 15:819823. https://doi.org/10.1093/treephys/15.12.819

Breshears DD, McDowell NG, Goddard KL, Dayem KE, Martens SN, Meyer CW, Brown KM (2008) Foliar absorption of intercepted rainfall improves woody plant water status most during drought. Ecology 89:41-47. https://doi.org/10.1890/07-0437.1

Burgess SSO, Dawson TE (2004) The contribution of fog to the water relations of Sequoia sempervirens (D. Don): foliar uptake and prevention of dehydration. Plant Cell Environ 27:1023-1034. https://doi.org/10.1111/j.13653040.2004.01207.x

Cape JN (1983) Contact angles of water droplets on needles of Scots pine (Pinus sylvesteis) growing in polluted atmospheres. New Phytol 93:293-299. https://doi.org/ 10.1111/j.1469-8137.1983.tb03432.x

Clemesha RES, Gershunov A, Iacobellis SF, Williams AP, Cayan DR (2016) The northward march of summer low cloudiness along the California coast. Geophys Res Lett 43:1287-1295. https://doi.org/10.1002/2015GL067081

Dawson TE (1998) Fog in the California redwood forest: ecosystem inputs and use by plants. Oecologia 117:476485. https://doi.org/10.1007/s004420050683

Dawson TE, Goldsmith GR (2018) The value of wet leaves. New Phytol 219:1156-1169. https://doi.org/10.1111/ nph. 15307

De Santo AV, Alfani A, De Luca P (1976) Water vapour uptake from the atmosphere by some Tillandsia species. Ann Bot 40:391-394. https://doi.org/10.1093/oxfordjour nals.aob.a085144

Dorrer C, Rühe J (2007) Condensation and wetting transitions on microstructured ultrahydrophobic surfaces. Langmuir 23:3820-3824. https://doi.org/10.1021/la063 $130 \mathrm{f}$

Eller CB, Lima AL, Oliveira RS (2013) Foliar uptake of fog water and transport belowground alleviates drought effects in the cloud forest tree species, Drimys brasiliensis (Winteraceae). New Phytol 199:151-162. https://doi.org/10. 1111/nph. 12248 
Emery NC (2016) Foliar uptake of fog in coastal California shrub species. Oecologia 182:731-742. https://doi.org/10. 1007/s00442-016-3712-4

Fernández V, Bahamonde HA, Javier Peguero-Pina J, Gil-Pelegrín E, Sancho-Knapik D, Gil L, Goldbach HE, Eichert T (2017) Physico-chemical properties of plant cuticles and their functional and ecological significance. J Exp Bot 68:5293-5306. https://doi.org/10.1093/jxb/erx302

Fischer DT, Still CJ, Williams AP (2009) Significance of summer fog and overcast for drought stress and ecological functioning of coastal California endemic plant species. J Biogeogr 36:783-799. https://doi.org/10.1111/j.13652699.2008.02025.x

Franklin J, Santos EV (2011) A spatially explicit census reveals population structure and recruitment patterns for a narrowly endemic pine, Pinus torreyana. Plant Ecol 212:293-306. https://doi.org/10.1007/s11258-010-9822-x

Goldsmith GR, Matzke NJ, Dawson TE (2013) The incidence and implications of clouds for cloud forest plant water relations. Ecol Lett 16:307-314. https://doi.org/10.1111/ ele. 12039

Haller JR (1986) Taxonomy and relationships of the mainland and island populations of Pinus torreyana (Pinaceae). Syst Bot 11:39-50. https://doi.org/10.2307/2418944

Hamilton JA, Royauté R, Wright JW, Hodgskiss P, Ledig FT (2017) Genetic conservation and management of the California endemic, Torrey pine (Pinus torreyana Parry): implications of genetic rescue in a genetically depauperate species. Ecol Evol 7:7370-7381. https://doi.org/10.1002/ ece 3.3306

IUCN (2021) The IUCN red list of threatened species. Version 2021-1. https://www.iucnredlist.org. Accessed 20 May 2021

Kerstiens G (1996) Cuticular water permeability and its physiological significance. J Exp Bot 47:1813-1832. https:// doi.org/10.1093/jxb/47.12.1813

Ledig FT, Conkle MT (1983) Gene diversity and genetic structure in a narrow endemic, torrey pine (Pinus torreyana parry ex carr.). Evolution 37:79-85. https://doi.org/10. 1111/j.1558-5646.1983.tb05515.x

Leyton L, Armitage IP (1968) Cuticle structure and water relations of the needles of Pinus radiata (D. Don). New Phytol 67:31-38. https://doi.org/10.1111/j.1469-8137.1968. tb05451.x

Leyton L, Juniper BE (1963) Cuticle structure and water relations of pine needles. Nature 198:770-771

Limm EB, Simonin KA, Bothman AG, Dawson TE (2009) Foliar water uptake: a common water acquisition strategy for plants of the redwood forest. Oecologia 161:449-459. https://doi.org/10.1007/s00442-009-1400-3

Lin J, Jach ME, Ceulemans R (2001) Stomatal density and needle anatomy of scots pine (Pinus sylvestris) are affected by elevated $\mathrm{CO}_{2}$. New Phytol 150:665-674. https://doi.org/ 10.1046/j.1469-8137.2001.00124.x

R Core Team (2021) R: a language and environment for statistical computing. $\mathrm{R}$ foundation for statistical computing, Vienna, Austria. URL https://www.R-project.org/. Accessed 14 Sept 2021

RStudio Team (2021) RStudio: integrated development environment for R. RStudio, PBC, Boston, MA. URL http:// www.rstudio.com/. Accessed 14 Sept 2021
Rundel PW (1982) Water uptake by organs other than roots. In: Lange OL, Nobel PS, Osmond CB, Ziegler H (eds) Physiological plant ecology II: water relations and carbon assimilation. Springer, Berlin, Heidelberg, pp 111-134

Schreel JDM, Steppe K (2020) Foliar water uptake in trees: negligible or necessary? Trends Plant Sci 25:590-603. https://doi.org/10.1016/j.tplants.2020.01.003

Steele SE, Ryder OA, Maschinski J (2021) RNA-Seq reveals adaptive genetic potential of the rare torrey pine (Pinus torreyana) in the face of Ips bark beetle outbreaks. Conserv Genet 22:1035-1050. https://doi.org/10.1007/ s10592-021-01394-7

Stone EC (1957a) Dew as an ecological factor: I. A Rev Lit Ecol 38:407-413

Stone EC (1957b) Dew as an ecological factor: II. The effect of artificial dew on the survival of Pinus ponderosa and associated species. Ecology 38:414-422

Stone EC, Went FW, Young CL (1950) Water absorption from the atmosphere by plants growing in dry soil. Science 111:546-548

Stone EC, Shachori AY, Stanley RG (1956) Water absorption by needles of ponderosa pine seedlings and its internal redistribution. Plant Physiol 31:120-126. https://doi.org/ 10.1104/pp.31.2.120

Torregrosa A, Combs C, Peters J (2016) GOES-derived fog and low cloud indices for coastal north and central California ecological analyses. Earth Space Sci 3:46-67. https://doi. org/10.1002/2015EA000119

Wang T, Hamann A, Spittlehouse D, Carroll C (2016) Locally downscaled and spatially customizable climate data for historical and future periods for North America. PLoS ONE 11:e0156720. https://doi.org/10.1371/journal.pone. 0156720

Wells ML, Getis A (1999) The spatial characteristics of stand structure in Pinus torreyana. Plant Ecol 143:153-170. https://doi.org/10.1023/A:1009866702320

Whittall JB, Syring J, Parks M, Buenrostro J, Dick C, Liston A, Cronn R (2010) Finding a (pine) needle in a haystack: chloroplast genome sequence divergence in rare and widespread pines. Mol Ecol 19:100-114. https://doi.org/10. 1111/j.1365-294X.2009.04474.x

Williams AP, Still CJ, Fischer DT, Leavitt SW (2008) The influence of summertime fog and overcast clouds on the growth of a coastal Californian pine: a tree-ring study. Oecologia 156:601-611. https://doi.org/10.1007/ s00442-008-1025-y

Yamasaki S, Dillenburg L (1999) Measurements of leaf relative water content in Araucaria Angustifolia. Rev Bras Fisiol Veg 11:69-75

Publisher's Note Springer Nature remains neutral with regard to jurisdictional claims in published maps and institutional affiliations. 